\title{
A Task-Based Personal Learning Environment for Developing the English Majors' Listening Comprehension Skills
}

By

\section{Dr. Mohammad Abu El-Magd Mohammad Abu El-Magd 2015}

\begin{abstract}
The purpose of this research was to develop the English Language Listening Comprehension skills for the English Major's freshmen at the Faculty of Education. The target Listening Comprehension Skills were: a) Basic Level Listening Comprehension Skills: (Guessing the meaning of unfamiliar words within the context of oral stories and song's spoken lyrics as well as Listening for gist in formal and informal conversations), b) High Level Listening Comprehension Skills: (Listening for implicit and explicit details in lectures as well as Listening for specifics from the weather reports and news reports). The participants were a group of $301^{\text {st }}$ year Majors of English at Ismailia Faculty of Education in Suez Canal University (SCU). The research design was one group pre- and post-test quasiexperimental design. The measurement tool was a Listening Comprehension test developed by the researcher. The findings revealed that the proposed Task-Based Personal Learning Environment (TBPLE) module had a significant positive effect on developing the target Listening Comprehension skills of the English major's freshmen.
\end{abstract}

Key Words: Task-Based Approach, TBA, Personal Learning Environment, PLE, Listening Comprehension, EFL Listening Skills, and Majors of TEFL.

* Lecturer of Methods of TEFL, Ismailia Faculty of Education, Suez Canal University, Egypt. 


\section{A Task-Based Personal Learning Environment for Developing the English Majors' Listening Comprehension Skills}

\section{Background and Problem}

In a community where English is learned as a foreign language, English learners are less exposed to listening materials. Although listening skills are of crucial importance in language intake and acquisition, listening lags behind the other skills. Consequently, most of the EFL learners have problems in listening comprehension and listening seems the most demanding skill (Rezaei \& Hashim, 2013). There is no exaggeration to mention that listening is an essential skill for communication in life since it allows us to engage in social rituals, exchange information, exert control, share feelings, and enjoy ourselves.

Listening is the primary language ability out of which all the other skills develop. It is only through listening first that individuals recognize the patterns in language which, in turn, is the basis of the whole process of language development. Moreover, Listening is the focus, or, first purpose for all speech activity and it can become a linguistic and social reality only when the speech code is understood (Natraj, 2005:1).Thus, Listening is an important component of the language teaching syllabus and listening exercises that have been properly prepared should be an ultimate integral adoption in a language course (Scott, 2008). In this respect, a study was conducted by Alam \& Sinha (2009) to incorporate the EFL (English as a Foreign Language) Listening Skills at the Tertiary Level in order to improve the learners' communicative competence.

In this regard, a content analysis was conducted by the researcher for the listening courses taken by English Majors at Ismailia Faculty of Education in order to check out whether the necessary listening comprehension skills are incorporated or not. The findings have proved that they are just pronunciation courses with discriminative listening skills. Other listening skills including the listening comprehension skills necessary for those students are almost missing. Moreover, the listening textbooks do not provide sufficient tasks with meaningful practice and they are not accompanied by supporting authentic materials; such as audio, video, and web-based or any other online resources that enhance the features of real-life listening. 
Since we learn listening skills in an EFL context for further use in real-life communications, we have to involve authentic listening tasks by using the TaskBased Approach (TBA). TBA has gained popularity in the field of language teaching since the last decade of the $20 \mathrm{fh}$ Century for it focuses on a meaningful and communicative language use as well as it takes the real world tasks as the source and model for pedagogical action (Ellis, 2003: 28-36). TBA does not present tasks as major components of methodology; however it provides a link between outside classroom reality and inside classroom pedagogy (Burton, 2002). Thus, TBA offers the opportunity for natural learning inside the classroom by placing the learner in a situation like in the real world.

On the other side, Personal Learning Environment (PLE), as one of the latest online E-learning approaches (Attwell,2007:1), it is a new construct in the e-learning literature that is premised on social media and steadily gaining ground in the eLearning field as an effective platform for student learning (Martindale \& Dowdy ,2010: 177-193). It helps the learners take control of their own learning and it connects between classroom based learning and the different unlimited authentic and various online resources; such as internet communication, books and journals, internet media (e.g. videos, audio and graphics) and blogs (Good, 2007).

Figure (1)

The Personal Learning Environment's link between classroom learning

and worldwide global resources

(Perry, 2008)

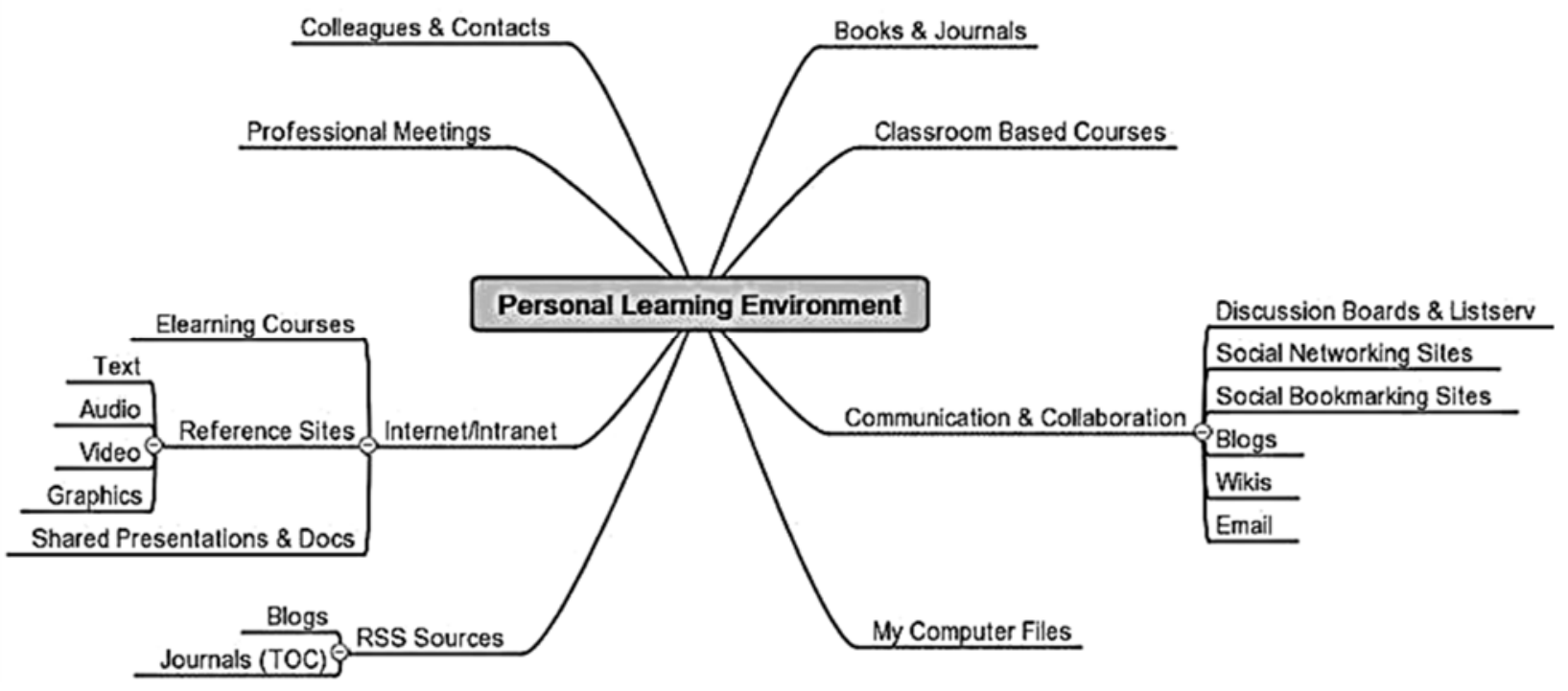

This figure shows that PLE plays a crucial role in creating learning experiences, which encourage students' autonomy and stimulate self- 
determined learning that prepares them for lifelong learning. It takes the advantages of the evolution of Web 2.0 technology and it aims at creating a learning environment where each learner is in control of his or her own learning goal(s), activity(s) and experience. PLE promotes self-regulation and learning autonomy in a learner, eventually promoting lifelong learning that crosses the boundary of higher education institution (Mokhtar \& Huoy, 2013).

In higher education, Reisas (2012) conducted a study to determine the relevance of facilitating knowledge explicit and implicit practices and personal learning environments. It has been found out that actual teaching and learning situations (in higher education) are affected significantly by personal learning environments and incorporated knowledge practices and that PLEs as activity systems are helpful for students to articulate knowledge practices. As for the EFL courses in higher education, Laakkonen conducted a study in 2011 to investigate the integration of PLE approach into language courses at the University of Jyväskylä Language Centre (Thouësny \& Bradley, 2011:922). The findings have proved that, in an EFL course, PLE can:

- Facilitate L2 communication in the classroom.

- Create meaningful context by adding "real world relevance"

- Facilitate joint content creation;

- Allow students to network, interact and share.

- Enhance learner-centeredness.

- Change the role of the student from that of participant to contributor.

- Link meaningful communication to real life situations, supports individual and peer processes, and encourages creativity and self-regulation.

Consequently, the TBA can be adopted in combination with the PLE in order to design a listening course that helps develop the necessary listening comprehension skills within various tasks with meaningful practice by using an endless number of different online resources as well as supporting authentic media (e.g. audio and video).

\section{Literature Review and Related Previous Studies}

Since this research aimed at determining the effect of a Task-based PLE on the listening skills of English majors, the literature review and related previous studies tackled the following parts: 
1. "The Listening Comprehension Skills"

In order to identify the necessary sub-skills for the English majors.

2. "The Task-based PLE (Personal Learning Environment)"

In order to shed the light on the nature of the Task-based PLE and its possible effects on developing the listening comprehension skills.

\section{The Listening Comprehension Skills:}

Listening means interpreting a text in a specific context by assigning, meaning to the sounds heard (Natraj, 2005:1). Listening is a complex of skills. Within such a complex of listening skills lies listening comprehension. OER (2012:34-35) and Engeleberg \& John (2013:31) state that listening comprehension is the ability of an individual to retain and understand a speaker's message as well as it focuses on accurately understanding the meaning of the speaker's words while simultaneously interpreting non-verbal cues such as facial expressions, gestures, posture, and vocal quality.

Listening Comprehension focuses on 'understanding the message that we hear', thus it is considered as the basis for the Therapeutic Listening, Critical Listening and Appreciative Listening (Goh, 2002: 38). Accordingly, lot of work in teaching listening in the classroom has to develop the learners' listening comprehension skills (Pugazhenthi, 2013).

At various levels of linguistic and cognitive competence, listening comprehension has got various sub-skills. The sub-skills of listening are competencies that native speakers possess and second/foreign language learners have to acquire (Abolfathiasl, 2013).

In this respect, Barta (2010) conducted a study to examine what listening comprehension sub-skills can be identified in an EFL course at high schools to enable the learners to pass the listening tests. In this study, she refers to the following 3 domains of listening comprehension skills: 1. Grammatical Knowledge (e.g. recognizing phonological features, syntax structures, lexis and cues of oral punctuation), 2. Discourse Knowledge (e.g. understanding main ideas, specifics and details), and 3. Sociolinguistic Knowledge (e.g. making inferences by social/situational contexts, background/real-world knowledge). In a study conducted by Crawford (2001) to develop the 
listening sub-skills of the learners in Hokkaido University of Education, 3 main listening comprehension sub-skills were focused on: Listening to questions and responding, Listening for specific information and Listening to descriptions.

Natraj (2005:1-2), Musa (2007) and Bengoa (2008) refer to the following listening comprehension skills:

- Literal level of listening comprehension which includes:

(a) Deducing the meaning of unfamiliar words within a context

(b) Recognizing relationships within the sentence: transitions, sequence markers and the syntactic and morphological forms of spoken language.

(c) Understanding phonological features (e.g. Hearing of sounds and the function of intonation).

[These literal listening comprehension skills ( $a, b$ and $c$ ) have been ranked as the most frequently used listening sub-skills in an EFL classroom in light of the study conducted by Rezaei \&Hashim (2013)]

(d) Understanding grammatical cohesive devices such as reference.

- Inferential level which consists of the following:

(a) Inferring the main ideas.

[Reading for main ideas has been ranked as the most frequently used listening sub-skills in an EFL classroom in light of the study conducted by Rezaei \&Hashim (2013)]

(b) Inferring about figurative language.

(c) Comparing between the old information and the new one

The National Capital Language Resource Center (2004), Scott (2008), Bengoa (2008), University of Cambridge (2009:3), Alam \& Sinha (2009), Fadwa (2010:4) as well as Iman et al (2011: 11-12) add the following listening comprehension sub-skills:

- Listening for specific information [Scanning]

- Listening for general information (gist) [Skimming]

- Listening for detailed information [Scanning]

- Identifying keywords and taking notes

- Ability to detect attitude of speaker toward subject matter 
[These sub-skill, mentioned above, has been ranked as the most frequently used listening sub-skills in an EFL classroom in light of the study conducted by Rezaei \&Hashim (2013)]

- Following topic development and shifts

- Predicting

- Recognizing word boundaries

\section{Conclusion:}

Depending on the previously mentioned listening comprehension skills in light of the literature review, an inventory of EFL Listening Comprehension skills was prepared to be submitted to jurors in the field of TEFL to identify the EFL Listening Comprehension skills that are necessary for and appropriate to the English Major's freshmen at the Faculty of Education. According to the jurors' views and the content analysis for the listening courses, the following EFL Listening Comprehension skills were used in the Task-based PLE:

1. Basic Level Listening Comprehension skills:

a. Guessing the meaning of unfamiliar words:

- Recognizing the meanings unfamiliar words within the context of oral stories.

- Identifying the meanings of unfamiliar words within the context of song's spoken lyrics.

b. Listening for gist:

- Identifying the main ideas in formal conversations.

- Determining the salient points in informal conversations.

2. High Level Listening Comprehension skills:

a. Listening for details:

- Highlighting explicitly stated information in lectures.

- Pointing out implicitly stated information in lectures.

b. Listening for specifics:

- Extracting specific information from the weather reports.

- Selecting specific information from the News reports. 


\section{The Task-based PLE (Personal Learning Environment):}

Since Task-based PLE is a combination between Task-based Approach and PLE, the following points were tackled in order to define the Task-based PLE in light of the research variables and delimitations as well as the possible impacts of this combination on EFL listening.

\subsection{Task-Based Approach (TBA):}

\subsubsection{TBA's definition:}

Ellis (2003: 16), Littlewood (2003: 324), Nunan (2004:1), Bruton (2005), Harmer (2007:71) and Lai \& Li (2011) define TBA as a TEFL approach that underpins and strengthens the following pedagogical principles and practices:

- A needs-based approach to content selection.

- An emphasis on learning to communicate through interaction in EFL (Learners' engagement in the task).

- An involvement of authentic texts into the learning situation.

- Learners' focus on language and the learning process itself.

- Connecting the learner's personal experiences with classroom learning.

- Linking classroom language learning with language use outside classroom.

- Learners choose the linguistic resources needed to complete the task.

- Assessing learners' performance in light of the tasks' outcomes.

-

According to the variables of the research, TBA can be defined as "An interactive learner-centered approach to teaching EFL listening comprehension skills within authentic video, audio and text-based tasks that assess learners' performance concerning the ILO's and that link between the learners' experiences, classroom learning and language used outside the class".

\subsubsection{TBA Stages:}

Willis (2002: 27-36), Plews and Zhao (2010), Willis (2013: 9) and Xiang (2013) share the following basic three stages for TBA: 
According to this figure, TBA goes through the following stages:

1. Pre-task (Introduction to the task)

In the pre-task, the teacher introduces the task, provides the instructions and informs the learners about the Intended Learning Outcomes (ILO's). Additionally, in the "weak" form of TBLL, the teacher may prime the students with key vocabulary or grammatical constructs; although this can mean that the activity is, in effect, more similar to the more traditional present-practiceproduce (PPP) paradigm. In "strong" task-based learning lessons, learners are responsible for selecting the appropriate language for any given context themselves. The instructors may also present a model of the task by either doing it themselves or by presenting picture, audio, or video demonstrating the task.

\section{Task (Task Cycle)}

During the task phase, the learners perform the task, typically in small groups, although this is dependent on the type of activity. Unless the teacher plays a particular role in the task, then the teacher's role is typically limited to one of an observer or counsellor - thus the reason for it being a more studentcentered methodology.

Task Performance $\longrightarrow$ Planning (Having completed the task, students prepare to report on the outcome. Now the emphasis is on organization and accuracy. The teacher advises students on language and helps them correct any errors they make during this phase) $\longrightarrow$ Report (Students compare findings).

\section{Review (Task Analysis/Language Focus)}

If learners have created tangible linguistic products, e.g. text, montage, presentation, audio or video recording, learners can review each other's work and offer constructive feedback.

Analysis of text (Learners focus on form and ask questions about language features) $\longrightarrow$ Practice of new patterns, words and structures (Teacher conducts activities based on the analysis work or examples from the text to transcript). 
3.2 Personal Learning Environment (PLE):

\subsubsection{PLE definition:}

A Personal Learning Environment or PLE is a potentially promising pedagogical approach for both integrating formal and informal learning using social media and supporting student self-regulated learning in higher education contexts (Dabbagh \& Kitsantas, 2012). To understand what a PLE is, it is important to understand that a PLE is not a software application (Wilson, 2008) or a method for creating e-learning applications (Scapin, 2009:17); it is a concept for organizing learning. There are a number of definitions of PLE that share the following features:

1. An organized collection of services to help learners create content and connections as well as tools to help learners gather, control and process learning resources.

2. A computer-based schema for self-directed learning in order to maintain organization of resources and help learners communicate with other learners and communities.

3. A system that may be composed of one or more subsystems; such as desktop application, or composed of one or more web-based services organized together. These are systems specifically designed or created by the combined use of various external applications or tools that can be used by the learners to form their own personal way of working, using the tools they feel are most appropriate to achieve their purpose.

(Martin, 2007; Downes ,2007; Johnson \& Brierley, 2007; Attwell, 2007:1; Waters, 2008; van Harmelen, 2008 and Panagiotidis, 2012)

To conclude, PLE is an independent learning based environment where people, communities, tools and resources interact in a very flexible way (Shaikh \& Khoja, 2012). Definitions vary from one person to another, but the primary element of PLE is learners' self-direction, content-creation, controls and interactions with various accessible resources using the available webservices and tools (Skrabut, 2013: 4-5). In light of the research variables, PLE can be procedurally defined as "A desktop application system with online video, audio and web-based searching services basically designed to help the learners develop their listening comprehension skills." 


\subsubsection{PLE Framework:}

PLE is not a specific software application, a substitute for institutional or regulatory agency required documentation of education/training compliance, or a method for creating e-learning applications; however it is a concept rather than specific software, a group of techniques and a variety of tools to gather information, and browse/explore/develop relationships between pieces of information (Perry, 2008).

"A PLE for an English as a foreign language (EFL) course may look like a mind map, in which she has grouped the tools and resources around the concepts of Cultural Competence, Language Competence, People \& Places, and Information, and then into subsections such as Informal/Formal and Listening, Speaking, Reading and Writing. There are as many ways to map a PLE as there are learners" (Thouësny \& Bradley, 2011:17-18).

Figure (2)

The PLE Framework of Connectivism

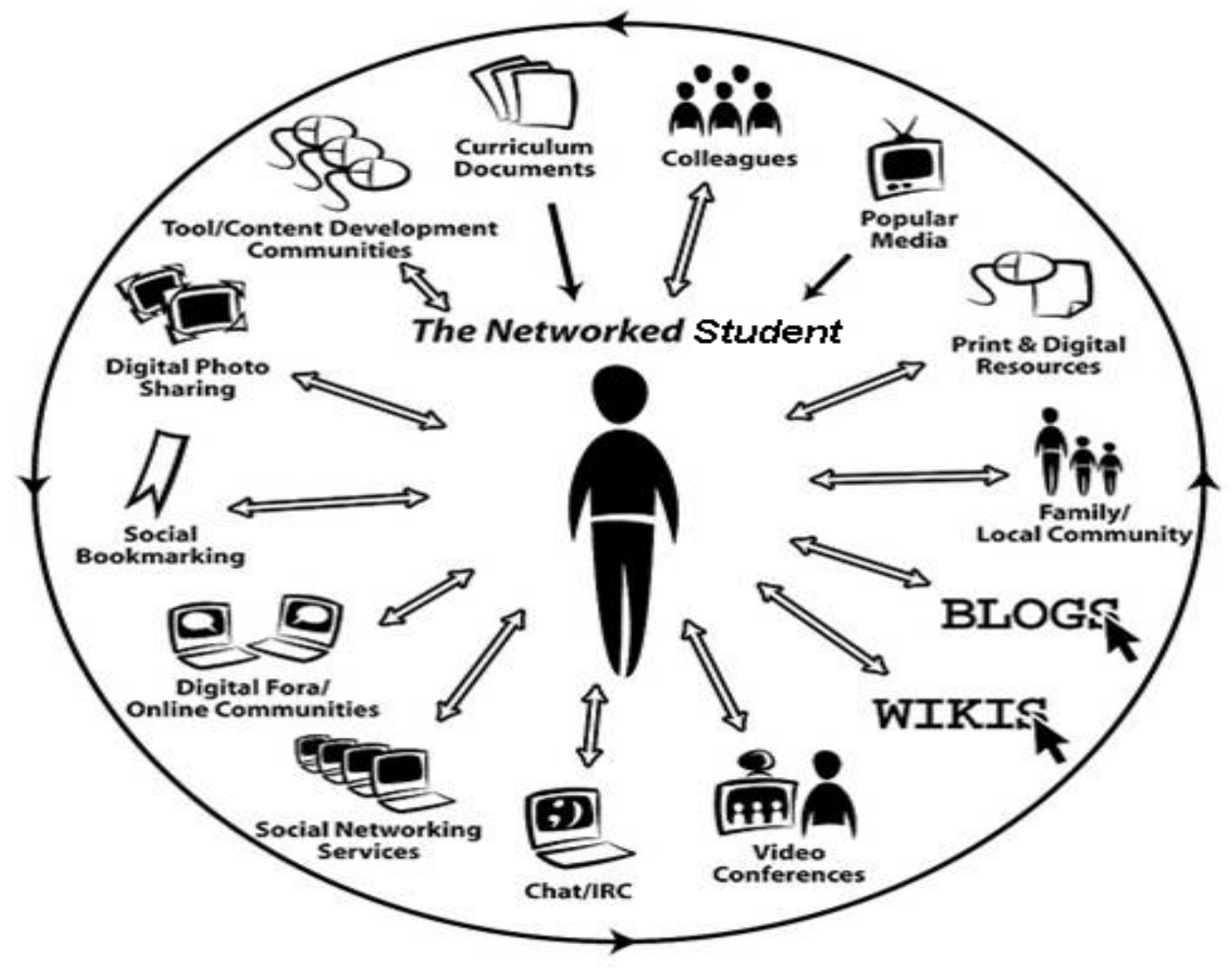

(Bedard-Voorhees, 2013:7) 
As shown in this figure, a PLE framework is based on Connectivism because PLE calls for the following principles: 1) Learning is a process of connecting specialized nodes or information sources, 2) A learner can exponentially improve their own learning by plugging into an existing network, 3) Knowing where to find information is more important than knowing information, 4) Learning is a knowledge creation process...not only knowledge consumption, 5) Learning happens in many different ways. Courses, email, communities, conversations, web search, email lists, reading blogs, etc, Courses are not the primary conduit for learning, 6) Information is changing constantly and located in so many places, 7) The ability to find, collect, connect and sort information among a multitude of human and computer networks is a critical skill and 8) Mashup: Web application that combines data from one or more sources into a single integrated tool (Scapin, 2009:13-15 and Islam, 2011).

In brief, a PLE should contain a) content, b) context, c) connections, d) collection, e) communication, f) community, g) collaboration, and h) creation (WikiEducator, 2010). Peña-López (2010) argue that an effective PLE may contain accessing, aggregating, manipulating, and analyzing knowledge, or in other words, a PLE may provide the facilities of reading, noting, thinking, and writing.

Since PLE is "An approach to learning directed by learners' needs \& interests and facilitated by a collection of tools" (EDUCAUSE Learning Initiative, 2009), learners should develop PLE based on their personal needs to make a PLE rewarding (Attwell, 2007: 23). Accordingly, The PLE, for developing the listening comprehension skills of the English majors' freshmen, was designed as shown in this figure: 


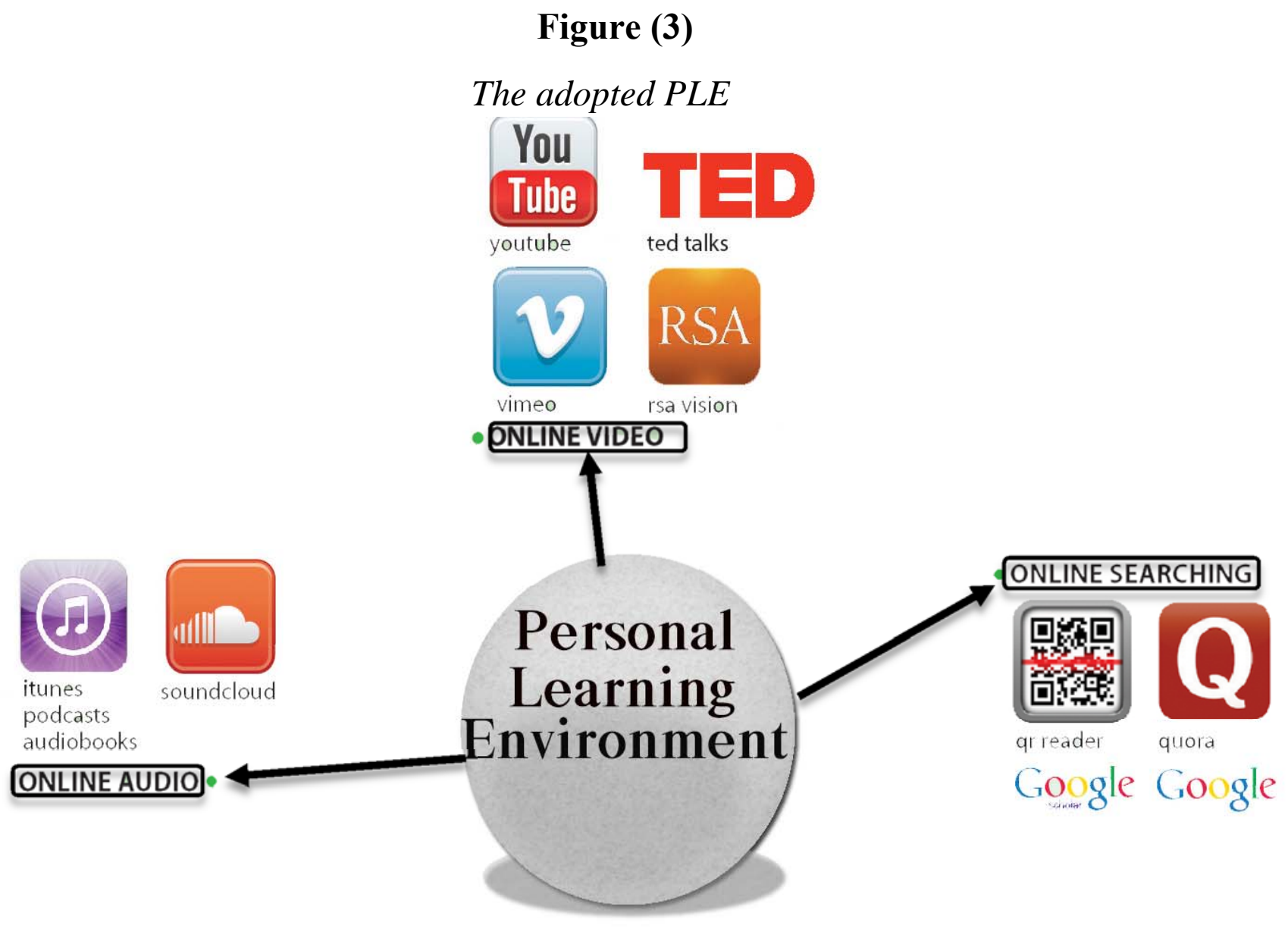

According to this figure, the PLE environment, adopted for developing EFL listening skills, should involve the following components:

- Online Video applications; such as You Tube, TED Talks, Vimeo and RSA Vision.

- Online Audio applications; such as itunes, Podcasts and Sound cloud.

- Online search engines for various audio and video resources; such as audio books/ channels and online video channels.

3.3 Task-based PLE (TBPLE):

3.3.1 Definition of TBPLE:

TBPLE is a blend between TBA and PLE as shown in this figure: 


\section{Figure (4)}

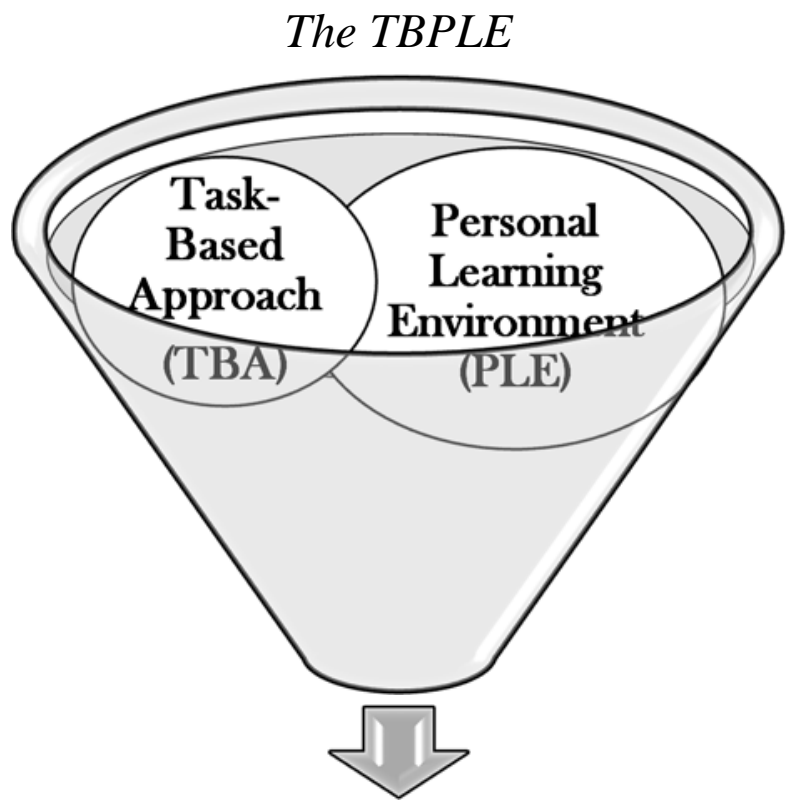

Task-Based Personal Learning Environment (TBPLE)

According to this figure and the procedural definitions of TBA and PLE in light of the research variables, TBPLE is "An interactive learner-centered desktop application system based on authentic online video, audio and textbased tasks that link between the learners' experiences, classroom learning and language used outside the class with web-based searching services basically designed to help the learners develop their listening comprehension skills and assess their performance concerning the ILO's."

\subsubsection{The rationale behind the blend between TBA and PLE:}

Technology and TBLT have become part of each other due to their elective theoretical and practical affinities (Ortega, 2009). Thomas and Reinders (2010) assert the potential synergy between TBA and the use of computer technology in developing and teaching language learners' realworld target tasks. In this respect, Lai and Li (2011) conducted a study on the technology and TBA. The results proved the reciprocal relationship between technology and TBA so that technology helps enhance learning from language tasks and TBA. Accordingly, a blend between TBA and PLE as one of the upto-date digital technology E-learning applications is necessary to: 
1. Overcome the shortcomings of TBA:

- Owing to the difficulty in the implementation of TBA in the language classroom due to the scarcity of task-based manuals and the difficulty in getting resources beyond textbooks and related materials (SA NCHEZ, 2004 and Thirachaimongkhonkun \& Fathet,2013), a mix should be made between TBA and PLE in order to overcome such drawbacks of implementation since PLE helps provide an unlimited number of online resources.

- In TBA, students may be unwilling to risk communicating 'freely' (Ellis,2003:43); however the PLE can encourage them to communicate (Skrabut, 2013: 13).

2. Promote the beneficial use of TBA:

- Since TBA emphasizes on the authenticity of language learning materials (SA NCHEZ, 2004), PLE can enhance such authenticity by providing authentic multimedia elements (Text, Audio, Video and Pictures) in a way that fosters learners' communicative language use (Thouësny \& Bradley, 2011:18).

- In light of the TBA's emphasis on the meaningful language practice through real life tasks, PLE can provide multimediabased contents from the real life of native speakers of English; such as real-life videos for News and Weather forecasts and audio for real-life recorded lectures and conversations (Skrabut, 2013: 13).

- As TBA calls for the learners' varied exposure to the target language skill(s) (Dave \& Williams, 2007), PLE can provide various resources for language learning in a way that makes language learning enjoyable and motivating for the learners.

- PLE, as one of the applications of E-learning technology, can help the learners self-monitor their progress (Thouësny \& Bradley, 2011:19) and, in turn, facilitates language learning while performing the task (Lai \& Li, 2011). In this regard, a study in CMC (Computer Mediated Communication) was conducted by Smith (2010:77-90) in which it has been found that on-the-go monitoring was correlated with enhanced linguistic complexity and lexical diversity in task performance so that the enhanced self-monitoring during online text-based task performance might 
have contributed to the increased accuracy in learners' language production in this communicative context.

- As TBA calls for connecting language learning inside the classroom with the language use outside, PLE makes the worldwide authentic listening resources (Audio and Video) available for the individual language learner.

- PLE can help learners control their learning environment in order to actively participate in task performance (Kenning, 2010 and Ragupathi, 2011) and TBA supports self-autonomy learning (Richards \& Rodgers, 2001:58-64). In Sauro's (2004) study, for example, less dominant speakers used text chat tactically to maintain a foothold in the conversation and support their language production during task performance.

- TBA provides content that resemble the real world communication (Foster, 2009), while PLE enriches such content with unlimited resources for real world communication (Skrabut, 2013: 13-14).

- Based on the tasks provided through TBA, PLE can facilitate learners' content creation in light of the provided tasks and the available web-tools and services (Skrabut, 2013: 14).

- PLE is based on the personalization of learning so that it can help the learners construct, regulate, and control their own learning (Johnson \& Liber, 2008).

- PLE integrates between formal learning (inside the institution) and the informal learning (outside the institution) (Dabbagh \& Kitsantas, 2012). In this case, PLE helps the learner accomplish the ILO's of the tasks identified by the tutor in the class by surfing the PLE for more related online-unlimited resources, services and tools to reach the accepted performance level. 
3. Support the PLE:

- As PLE claims the establishment of a personal environment for learning online, TBA confirms building learner-centered language tasks so that the content and skills arise from the learners' needs (Willis \& Willis, 2007).

- As PLE creates the environment that support learners' communication in learning (Thouësny \& Bradley, 2011:19), TBA calls for communicative language teaching.

- The roles of instructors in a PLE also transform to a guide, facilitator, aggregator, advisor (Downes, 2007), and TBA calls for learner-centered learning.

4. Resolve the pedagogical problematic issues of PLE:

- In PLEs, more responsibility is placed on the learners and there is a risk of misconceptions of informal learning (Johnson \& Liber, 2008). TBA can control such informal learning since the learner is informed about the ILO's (Intended Learning Outcomes) of the provided desktop-based tasks and is responsible to accomplish them to reach the mastery level so that the PLE works as a means to provide online-unlimited authentic resources for more practice on the target skill in the provided tasks. Thus, the learner should surf the PLE seriously to accomplish the ILO's of the provided desktop-based tasks in case of failure to reach mastery level.

- In PLE, learners are responsible for organizing their own knowledge with a PLE rather than have the organization forced upon them (CETIS, 2006). In the planning stage of TBA, learners can get assistance for using their PLE to accomplish the ILO's and perform their tasks to reach the mastery level.

\subsubsection{TBPLE Framework:}

In light of the frameworks of the TBA and PLE, The following figure shows the layout of the tasks of each ILO in each lesson in the TBPLE module. 


\section{Figure (5)}

The Layout of each ILO in each lesson in TBPLE module

\section{Reading the Instructions}

\section{Reading the ILO of the} three listening Tasks

\section{Working on the tasks individually on the computer}

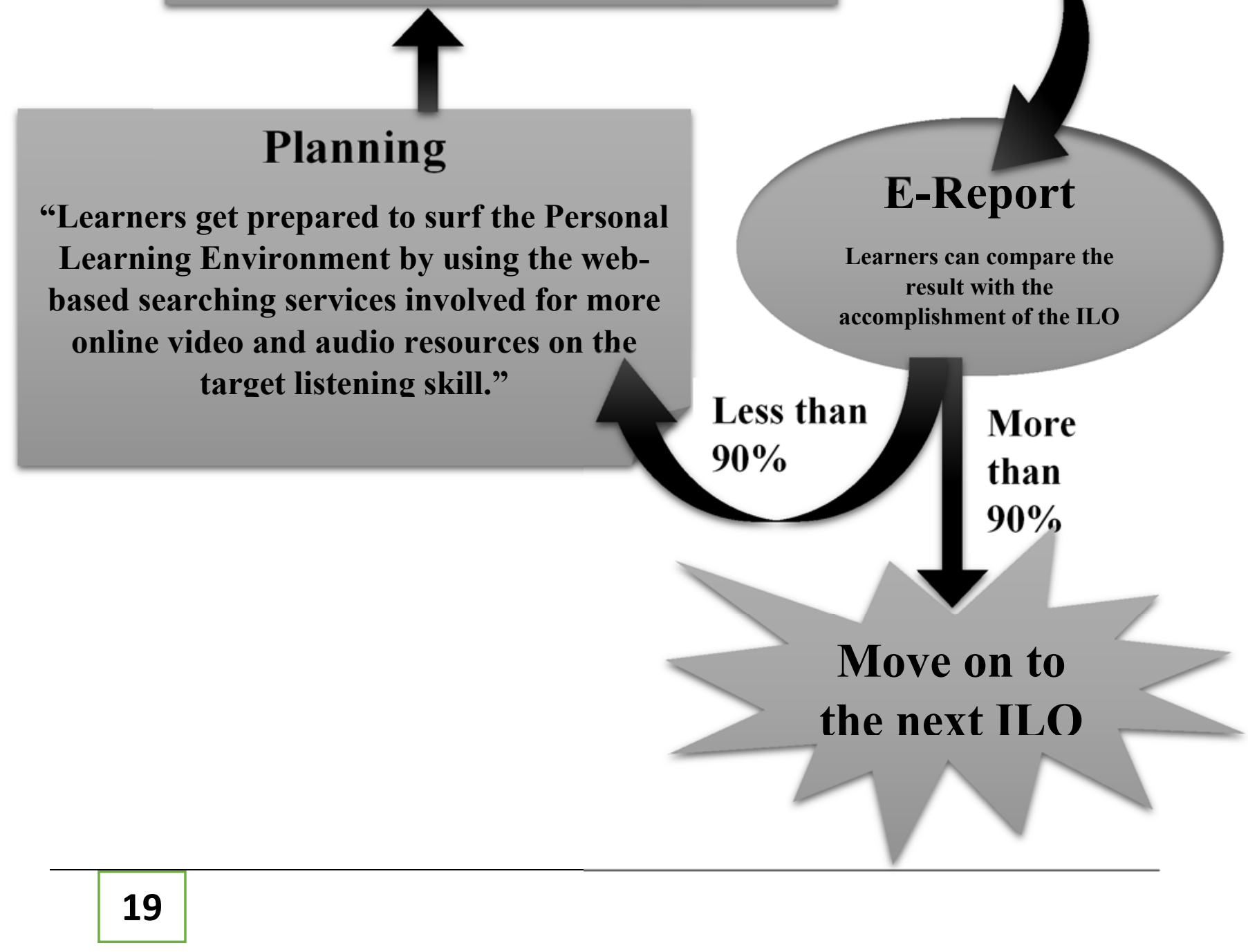


According to this figure, there are five main stages for TBPLE as follows:

1. Reading the Instructions of the task:

Before starting the listening tasks, the students should read the instructions for task performance.

2. Reading the ILO's of the task:

Immediately after getting the instructions, the students should read the ILO's (Intended Learning Outcomes) which inform their about the expected behavior and performance level at the end of the tasks.

3. Task performance:

Once the students get what is expected from them, they work on the tasks individually on the computer to accomplish the ILO's and meet their expected performance level.

4. E-Report:

When students are done with their tasks, they get their score on the computer with interpretation for how the accomplishment of the ILO's meets their expected performance level. Accordingly, students can compare between their score and the accomplishment of the ILO's so that:

a. If they get more than $90 \%$, they move on to the next ILO of the same or the next lesson.

b. If they get less than $90 \%$, they move on to the planning stage (no.5).

5. Planning:

Since the 'pedagogy' behind the PLE is that it offers a portal to the world, through which learners can explore and create, according to their own interests and directions, interacting at all times with their friends and community (Scapin, 2009: 30), in this stage, the students should start surfing the PLE designed for developing the listening comprehension skills by using the following web-based tools, services and applications:

- Online Video applications; such as You Tube, TED Talks, Vimeo and RSA Vision.

- Online Audio applications; such as itunes, Podcasts and Sound cloud.

- Online search engines for various audio and video resources; such as audio books/ channels and online video channels; such as BBC Learning English, BBC News 
3.3.4 TBPLE and Listening:

As for listening, Penny Ur (1984, page 9) emphasizes on the following features of most real-life listening:

1. We listen for a purpose and with certain expectations

2. There are some visual or environmental clues as to the meaning of what we is heard-Video only

3. Most heard discourse is spontaneous - while interviewees' discourse might be spontaneous, the newsreader's is not.

Since TBPLE is a mix between TBA and PLE, so TBPLE can make the listening purposeful because TBA is purpose oriented and PLE helps link the language learning in the classroom with learners' prior knowledge and real life by offering a portal to the world through which learners can explore and create, according to their own interests and directions, interacting as they choose, with their friends and learning community (Attwell, 2007:1).

Moreover, TBPLE can provide authentic real life listening discourse, spontaneous or non-spontaneous, since PLEs can help users approach the language and its native speakers much easier and in a richer context than traditional VLE systems (Panagiotidis, 2012). Additionally, TBPLE can help learners with visual or environmental clues as to the meaning of the listening discourse since PLEs can support many educational practices-both informal and formal - and many information literacy goals, from source selection, creation of effective search strategies, and better understanding of the information around a specific topic, through an unlimited variety of video sources they can concentrate in a common space (Kolah \& Fosmire, 2010).

In conclusion, a TBPLE is expected to meet the features of most real-life listening and therefore it can have positive possible effects on developing the listening comprehension skills for the Majors of English at the faculty of Education. 


\section{Statement of the problem}

In spite of the importance of listening for the English Majors at the Faculty of Education to be competent language teachers in their future career, the listening comprehension skills (e.g. guessing unfamiliar words within a spoken context as well as listening for gist, specifics and details) are almost missing from the content of the listening courses in light of the pilot content analysis. Therefore, this research sought to find answers to the following questions:

1. What are the listening comprehension sub-skills mostly necessary for the freshmen of English major at the Faculty of Education?

2. What are the features of a proposed Task-based PLE?

3. What is the effect of the proposed Task-based PLE on developing the listening comprehension sub-skills of the freshmen of English major at the Faculty of Education?

\section{Hypotheses}

1. There are statistically significant differences between the mean scores of the pre- and post-measurements of the basic level Listening Comprehension subskills in favor of the post-measurement.

2. There are statistically significant differences between the mean scores of the pre- and post-measurements of the high-level Listening Comprehension subskills in favor of the post-measurement.

3. There is a statistically significant difference between the mean scores of the pre- and post-measurements of the overall Listening Comprehension skills in favor of the post-measurement.

\section{Aims}

1. Designing a Task-based PLE for the developing the listening comprehension skills of the freshmen of English major at Ismailia Faculty of Education.

2. Determining the effect of teaching the developed Task-based PLE on the listening comprehension skills of the freshmen of English major at Ismailia Faculty of Education. 


\section{Delimitations}

This research was delimited to the following:

1. The freshmen of English major at Ismailia Faculty of Education in Suez Canal University in Egypt.

2. The following eight Listening Comprehension Sub-Skills:

A. Four Basic Level Listening Comprehension Skills (Skimming) as follows

\section{Guessing the meaning of unfamiliar words}

- Recognizing the meanings unfamiliar words within the context of oral stories

- Identifying the meanings of unfamiliar words within the context of song's spoken lyrics.

$>$ Listening for gist

- Identifying the main ideas in formal conversations.

- Determining the salient in informal conversations.

B. Four High Level Listening Comprehension Skills (Scanning) as follows

Listening for details

- Highlighting explicitly stated information in lectures.

- Pointing out implicitly stated information in lectures.

$>$ Listening for specifics

- Extracting specific information from the weather reports.

- Selecting specific information from the News reports

Because of the following:

- Listening comprehension skills are the basis for the other skills of listening; such as Therapeutic Listening, Evaluative Listening, Informational (Content) Listening, Attentive Listening, Critical Listening and Appreciative Listening (BBC British Council, 2011).

- In light of the preliminary investigation of the content analysis, these listening comprehension skills are almost missing in the Listening Courses of the $1^{\text {st }}$ year and $2^{\text {nd }}$ Majors of English at Ismailia Faculty of Education.

- These listening comprehension skills have been ranked by the jurors as the mostly needed ones by the freshmen of English Major at the Faculty of Education in order of priority. 


\section{Method}

1. The design:

The One Group Pre and Post Test Design.

2. The participants:

$301^{\text {st }}$ year majors of English at Ismailia Faculty of Education in the first semester of the academic year 2014-2015. Those participants were not resitters, they had deficits in their performance of the listening comprehension skills and their ages ranged between 17 and 18 years old.

3. The instrument:

A Listening Comprehension Test, which is composed of two parts. Part one for testing the basic level listening comprehension skills and part two for testing the high level listening comprehension skills. Each of these parts contains three types of questions: Multiple Choice, True or False and Matching. For the content validity of the listening test, a check list was submitted to a Jury Committee in the field of TEFL to verify the test items' representation of the intended learning outcomes. This checklist presented the intended learning outcomes accompanied by their related test items, and a 3 level scale of consistency (Inconsistent, consistent and very consistent) between each of the intended learning outcomes and their test items. Finally, all modifications were made. On the other hand the reliability of the listening test was checked administering the test to (20) 1st year students from the English Department at Ismailia Faculty of Education who were not participatory in the treatment. Finally, the researcher used $(\alpha)$ formula in order to estimate the reliability coefficient. The value of the reliability coefficient was $(82.1 \%)$. Thus, the listening test's reliability was established. 


\section{The program}

\section{Table (1)}

The lessons, their ILO's and listening comprehension Sub-skills in the Task Based PLE

\begin{tabular}{|c|c|c|}
\hline \multicolumn{3}{|c|}{ Listening Comprehension Module (Level: Intermediate) } \\
\hline Lessons & $\begin{array}{c}\text { ILO's } \\
\text { (Intended Learning Outcomes) }\end{array}$ & $\begin{array}{c}\text { The Listening } \\
\text { Comprehension } \\
\text { Sub-skills }\end{array}$ \\
\hline $\begin{array}{c}\text { One } \\
\text { (Stories and Songs) }\end{array}$ & $\begin{array}{l}\text { 1. Recognizing the } \\
\text { meanings of unfamiliar } \\
\text { words in oral stories. } \\
\text { 2. Identifying the } \\
\text { meanings of unfamiliar } \\
\text { words within the } \\
\text { context of songs' } \\
\text { spoken lyrics. }\end{array}$ & $\begin{array}{l}\text { Listening to guess the } \\
\text { meanings of unfamiliar } \\
\text { words. }\end{array}$ \\
\hline $\begin{array}{c}\text { Two } \\
\text { (Formal and Informal } \\
\text { Conversations) }\end{array}$ & $\begin{array}{l}\text { 1. Identifying the main } \\
\text { ideas in formal } \\
\text { conversations. } \\
\text { 2. Determining the } \\
\text { salient in informal } \\
\text { conversations. }\end{array}$ & Listening for gist \\
\hline $\begin{array}{c}\text { Three } \\
\text { (T.V Shows: Weather } \\
\text { and News Reports) }\end{array}$ & $\begin{array}{l}\text { 1. Extracting specific } \\
\text { information from the } \\
\text { weather reports. } \\
\text { 2. Selecting specific } \\
\text { information from the } \\
\text { News reports. }\end{array}$ & Listening for Specifics \\
\hline $\begin{array}{c}\text { Four } \\
\text { (Lectures) }\end{array}$ & $\begin{array}{l}\text { 1. Highlighting explicitly } \\
\text { stated information in } \\
\text { lectures. } \\
\text { 2. Pointing out implicitly } \\
\text { stated information in } \\
\text { lectures. }\end{array}$ & Listening for details \\
\hline
\end{tabular}


As shown in the table above, there are four lessons in a PLE-based Module and there are 6 tasks in each lesson so that there are 3 tasks for each ILO (Intended Learning Outcome) and there are 2 ILO's in each lesson. The learner should get $90 \%$ for the tasks of each ILO in order to move on to the next ILO of the same or the next lesson. However, the learner should get $80 \%$ as an external mastery level for the final test of the whole module.

\section{The Treatment}

Applying the TBPLE based module in the first semester of the academic year 2014-2015 (4 weeks/ 2 days per week / 4 hours per day) so that the total hours of instruction was 32 hours.

\section{Findings and discussion of results}

Investigating the experimental hypotheses by conducting paired-samples T-test as follows:

1. Hypothesis I stated " There are statistically significant differences between the mean scores of the pre- and post-measurements of the basic level Listening Comprehension sub-skills in favor of the post-measurement." The T-Test paired was used to test this hypothesis. The following table shows the related findings:

\section{Table (2)}

T-Test value of the difference between the mean scores of the

Pre and Post-measurements of the basic level

Listening comprehension sub-skills

\begin{tabular}{|l|l|l|l|l|l|}
\hline & $\begin{array}{l}\text { Number of } \\
\text { Participants }\end{array}$ & $\begin{array}{l}\text { Mean } \\
\text { Scores }\end{array}$ & $\begin{array}{l}\text { Standard } \\
\text { Deviation }\end{array}$ & T-Value & Significance \\
\cline { 1 - 5 } $\begin{array}{l}\text { Pre- } \\
\text { measurement }\end{array}$ & 30 & 43.2333 & 10.07449 & -16.734 & .000 \\
\cline { 1 - 5 } $\begin{array}{l}\text { Post- } \\
\text { measurement }\end{array}$ & & 71.5333 & 3.95434 & & \\
\hline
\end{tabular}

The table above demonstrates that the T-Value is significant at (0.05) level. 
The "Effect Size" (Eta-squared) for this hypothesis was estimated by using Eta-squared:

$$
\eta^{2}=\frac{T^{2}}{T^{2}+d f}
$$

The table below shows the related findings:

Table (3)

The Effect Size level of the TBPLE module on the basic level listening comprehension sub-skills

\begin{tabular}{|l|l|c|l|l|l|}
\hline Independent variable & $\begin{array}{l}\text { Dependent } \\
\text { variable }\end{array}$ & $\begin{array}{c}\mathrm{T}^{2} \\
\text { Value }\end{array}$ & $\mathrm{DF}$ & $\eta^{2}$ & $\begin{array}{l}\text { Effect } \\
\text { Size level }\end{array}$ \\
\hline The TBPLE module & $\begin{array}{l}\text { Basic level } \\
\text { listening } \\
\text { comprehension } \\
\text { sub-skills }\end{array}$ & 280.026756 & 29 & 0.90 & $\begin{array}{l}\text { Very } \\
\text { High }\end{array}$ \\
\hline
\end{tabular}

Accordingly, the TBPLE module had a high and positive effect on the basic level listening comprehension sub-skills of the freshmen majors of English. Thus, the hypothesis was accepted.

In light of the features of PLE, this significance may be due to the PLE's Facilitation of L2 communication in the classroom as referred to by Thouësny \& Bradley (2011:19) as well as PLE's role in the enrichment of the content with unlimited resources for real world communication and encouragement of learners to communicate freely as approved by Skrabut (2013: 13-14). This finding goes in line with a study conducted by Laakkonen (2011) which verified that PLE can create meaningful context by adding "real world relevance", facilitate joint content creation, enhance learner-centeredness, encourage learners' creativity and self-regulation, and change the role of the student from that of participant to contributor. 
As for TBA, this significance may also be due to the fact that TBA enhances learners' engagement in tasks, the involvement of authentic texts into the learning situation, learners' focus on language and the learning process itself, the connection between learner's personal experiences and classroom learning as a link between classroom language learning and language use outside classroom as well as the goal-oriented assessment for the learners' performance as stated by Ellis (2003: 16); Littlewood (2003: 324); Nunan (2004:1); Bruton (2005); Harmer (2007:71) and Lai and Li (2011). This finding is in line with the study conducted by Sauro's (2004) in which TBA has been revealed to enhance learner's self-autonomy learning.

Consequently, the verification of this hypothesis may be due to the combination between TBA and PLE.

2. Hypothesis II stated " There are statistically significant differences between the mean scores of the pre- and post-measurements of the High-level Listening Comprehension sub-skills in favor of the post-measurement." The T-Test paired was used to test this hypothesis. The following table shows the related findings:

\section{Table (4)}

T-Test value of the difference between the mean scores of the Pre and Post-measurements of the High-level

Listening comprehension sub-skills

\begin{tabular}{|l|l|l|l|l|l|}
\hline & $\begin{array}{l}\text { Number of } \\
\text { Participants }\end{array}$ & $\begin{array}{l}\text { Mean } \\
\text { Scores }\end{array}$ & $\begin{array}{l}\text { Standard } \\
\text { Deviation }\end{array}$ & T-Value & Significance \\
\hline $\begin{array}{l}\text { Pre- } \\
\text { measurement }\end{array}$ & 30 & 31.9000 & 8.28522 & -30.354 & .000 \\
\cline { 1 - 5 } $\begin{array}{l}\text { Post- } \\
\text { measurement }\end{array}$ & & 65.1000 & 6.34279 & & \\
\hline
\end{tabular}

The table above demonstrates that the T-Value is significant at (0.05) level. 
The "Effect Size" (Eta-squared) for this hypothesis was estimated by using Eta-squared. The table below shows the related findings:

\section{Table (5)}

The Effect Size level of the TBPLE module on the high-level listening comprehension sub-skills

\begin{tabular}{|c|l|c|l|l|l|}
\hline \multicolumn{1}{|c|}{$\begin{array}{c}\text { Independent } \\
\text { variable }\end{array}$} & $\begin{array}{l}\text { Dependent } \\
\text { variable }\end{array}$ & $\begin{array}{c}\mathrm{T}^{2} \\
\text { Value }\end{array}$ & $\mathrm{DF}$ & $\eta^{2}$ & $\begin{array}{l}\text { Effect } \\
\text { Size level }\end{array}$ \\
\hline The TBPLE module & $\begin{array}{l}\text { High-level } \\
\text { listening } \\
\text { comprehension } \\
\text { sub-skills }\end{array}$ & 921.365316 & 29 & 0.96 & $\begin{array}{l}\text { Very } \\
\text { High }\end{array}$ \\
\hline
\end{tabular}

Accordingly, the TBPLE module had a high and positive effect on the highlevel listening comprehension sub-skills of the freshmen majors of English. Thus, the hypothesis was verified.

In light of the features of PLE, this significance may be due to the PLE's Facilitation of L2 communication in the classroom as referred to by Thouësny \& Bradley (2011:19), PLE as an integration between formal learning and the informal learning as claimed by Dabbagh \& Kitsantas (2012) and PLE as a system that helps learners approach the language and its native speakers much easier and in a richer context as stated by Panagiotidis (2012). This finding is in line with the findings of Smith's study (2010:77-90) that confirm PLE's promotion of learners' self-monitoring their progress.

As for TBA, this significance may also be due to the fact that TBA enhances learners' engagement in tasks, the involvement of authentic texts into the learning situation, learners' focus on language and the learning process itself, the connection between learner's personal experiences and classroom learning as a link between classroom language learning and 
language use outside classroom as well as the goal-oriented assessment for the learners' performance as stated by Ellis (2003: 16); Littlewood (2003: 324); Nunan (2004:1); Bruton (2005); Harmer (2007:71) and Lai and Li (2011). This finding is in line with the study conducted by Sauro's (2004) in which TBA has been revealed to enhance learner's self-autonomy learning.

Consequently, the verification of this hypothesis may be due to the combination between TBA and PLE.

3. Hypothesis III stated " There is a statistically significant difference between the mean scores of the pre- and post-measurements of the overall Listening Comprehension skills in favor of the post-measurement." The T-Test paired was used to test this hypothesis. The following table shows the related findings:

Table (6)

$\mathrm{T}$-Test value of the difference between the mean scores of the

Pre and Post-measurements of the Overall

Listening comprehension skills

\begin{tabular}{|l|l|l|l|l|l|}
\hline & $\begin{array}{l}\text { Number of } \\
\text { Participants }\end{array}$ & $\begin{array}{l}\text { Mean } \\
\text { Scores }\end{array}$ & $\begin{array}{l}\text { Standard } \\
\text { Deviation }\end{array}$ & T-Value & Significance \\
\cline { 1 - 4 } $\begin{array}{l}\text { Pre- } \\
\text { measurement }\end{array}$ & \multirow{2}{*}{$\begin{array}{l}\text { Post- } \\
\text { measurement }\end{array}$} & 75.1000 & 15.30911 & -25.715 & .000 \\
\cline { 1 - 3 } & & $1.3653 \mathrm{E} 2$ & 6.66299 & & \\
\hline
\end{tabular}

Table (5) above demonstrates that the T-Value is significant at (0.05) level.

The "Effect Size" (Eta-squared) for this hypothesis was estimated by using Eta-squared. The table below shows the related findings: 


\section{Table (7)}

The Effect Size level of the TBPLE module on the overall listening comprehension skills

\begin{tabular}{|l|l|c|l|l|l|}
\hline Independent variable & $\begin{array}{l}\text { Dependent } \\
\text { variable }\end{array}$ & $\begin{array}{c}\mathrm{T}^{2} \\
\text { Value }\end{array}$ & $\mathrm{DF}$ & $\eta^{2}$ & $\begin{array}{l}\text { Effect } \\
\text { Size level }\end{array}$ \\
\hline The TBPLE module & $\begin{array}{l}\text { overall } \\
\text { listening } \\
\text { comprehension } \\
\text { skills. }\end{array}$ & 661.261225 & 21 & 0.95 & $\begin{array}{l}\text { Very } \\
\text { High }\end{array}$ \\
\hline
\end{tabular}

Accordingly, the TBPLE module had a high and positive effect on the overall listening comprehension skills of the freshmen majors of English.

\section{Discussion of the qualitative data:}

This section focused on discussing the students' responses towards using their TBPLE while practicing listening. First, during the treatment, the following students' comments were jotted down: "At the beginning, we have been afraid since we were accustomed to learning formally. We feel like learning the language informally", "We learn the language through authentic and real life situations as native speakers", "It is useful to listen to different voices of native speakers", "We are happy to design our content for language learning", "We do not get bored because we listen to various, up-dated and unlimited audio and video resources", "This is the best way to practice listening since we don't have to re-study the same content when we fail to reach the mastery level", "We wish to practice other different listening skills this way", "Because we are free to control what we learn and design our content, TBPLE considers the individual differences regarding the speed of learning and the different learning styles" and "We need to learn the other language skills using the TBPLE since it looks like a native speakers' language learning community". 
In light of the comments mentioned above, it can be concluded that TBPLE provides various unlimited resources for language learning, enhances the authenticity of language learning materials that resemble real world communication, personalizes learning by learner-centered language tasks that change the learners' role into self-controller, self-regulator and self-designer, emphasizes the meaningful language practice through real life tasks as well as integrates formal and informal language learning.

However, during the treatment, some remarkable observations were recorded. When the students surfed their TBPLEs for the first time, they did not accomplish the ILO's. Most of them managed to accomplish the ILO's after the third time. This may be due to the following:

$>$ Irresponsibility of some students when they surfed the related pages in their TBPLEs.

Low-level performance of the students' target listening comprehension skills so that they needed more practice and training.

D Students took long time to get accustomed to their TBPLEs through which they practice their target listening comprehension skills.

Also, all students asked for other PLEs that help them practice more language skills and asked to extend the time of the program for having the pleasure of practicing the listening skills informally. It was noticed that combining TBA and PLE has made the practicing listening skills different since the stand alone TBA depends on just providing specific number of tasks by the teacher. However, PLE allows the learner to control his learning and design his content using unlimited and updated authentic audio and video resources taken from or resemble real life communication. In conclusion, the previously stated and analyzed data for the 
students' comments and the researcher's remarkable notes were in line with the discussed findings.

\section{Recommendations and Suggestions}

Recommendations:

The following are the recommendations of the current study:

1. Faculties of education should mix between Task-based approach and Personal Learning Environment when developing the students' English language listening, speaking, reading and writing skills.

2. Having the learners control their learning and design their content by using PLEs.

3. Staff members' role is a facilitator and aggregator by building the PLEs that involve the tools, programs and services necessary for language learning and in light of the target ILO's of the language course.

4. The development and use PLEs should enhance the authenticity of language learning materials.

5. Combining TBA and PLE when teaching English courses.

Suggestions:

Here are some suggestions for possible further researches:

1. The Effect of using TBPLE on developing the listening skills of the students at the faculty of tourism.

2. A proposed TBPLE Business English Program for developing the language skills of the students at the faculty of Commerce.

3. Determining the effect of PLE on other language skills of the majors of English at the faculty of education. 
4. Conducting the current study on the EFL skills of the in-service teachers of English at schools.

5. Conducting studies on using PLE to teach ESP courses and develop the majors' EFL skills at different faculties; such as faculty of computer.

6. Conducting studies on using PLE to develop the learners' EFL skills in different stages at schools.

\section{References}

Abolfathiasl, H. (2013), “The Effect of Metacognitive Listening Strategy Training on EFL Learners' Listening Sub-skills Performance", International Journal of Applied Linguistics \& English Literature, Vol.2, No.4: 50-55

Alam, Z. \& Sinha, B.S. (2009), "Developing Listening Skills for Tertiary Level Learners", The Dhaka University Journal of Linguistics, Vol. 2, No.3: $51-85$

Attwell G. (2007), Personal Learning Environments - the future of eLearning? , eLearning Papers.

Barta, E. (2010), “TEST TAKERS' LISTENING COMPREHENSION SUB-SKILLS AND STRATEGIES”, WoPaLP, Vol. 4: 59-85

Bedard-Voorhees,A. (2013), Personal Learning Environments, Colorado: Elearning Consortium of Colorado.

Bengoa,M. (2008), LISTENING SUB SKILLS, http://miquelbenqoa.com/elt/? $\underline{p=86}$, Retrieved in August 2014.

Burton, A. (2002), "From tasking purposes to purposing tasks", ELT Journal, Vol. 56, No.3: 280-288

Bruton, A. (2005), “Task Based Language Learning: For the state secondary FL classroom”, Language Learning Journal, No 31: 55-68 
CETIS. (2006), The personal learning environments reference model project. JISC CETIS Wiki, http://wiki.cetis.ac.uk/Ple, retrieved in June 2013

Crawford,M. J. (2001), "Developing Listening Sub-skills with Trivia", The Language Teacher Online, http://jalt-publications.org/old_tlt/articles /2001/05/crawford, Retrieved in June 2014

Dabbagh,N. \& Kitsantas,A. (2012), "Personal Learning Environments, social media, and self-regulated learning: A natural formula for connecting formal and informal learning", The Internet and Higher Education, Vol. 15, No.1:3-8

Downes, S. (2007), "Learning networks in practice", Emerging Technologies for Learning, Vol.2: 19-27

EDUCAUSE. (2009), "7 Things you should know about Personal Learning Environments by Learning Initiative", Educause annual conference, 129

Ellis, R. (2003), Task-based Language Learning and Teaching, Oxford: Oxford University Press.

Engeleberg, I. N. and John A. Daly. (2013), Think: Public Speaking, USA: Pearson Education, Inc.

Fadwa,D.A.J. (2010), TEACHING THE RECEPTIVE SKILLS, KSA: Umm Al Qura University

Foster, P. (2009), "Task-based language learning research: expecting too much or too little?", International Journal of Applied Linguistics, Vol.19, No.3: $247-263$.

Goh, C.C. (2002), Teaching listening in the language classroom, Singapore: SEAMEO Regional Language Centre.

Good, R. (2007), Personal Learning Environments, http://www.masternewmedia. org/learning_educational_technologies/learning-environments/PLEpersonal-learning-environments-present-future-20070615.htm, retrieved in April 2014 
Iman, A. et al. (2011), The effectiveness of using an explicit language learning strategy-based instruction in developing secondary school students' EFL listening comprehension skills, Benha University: Faculty of Education.

Islam,M. N. (2011), "Independent English Learning through the Internet", Journal of Language Teaching and Research, Vol.2, No.5: 1080-1085

Johnson, M. \& Brierley, C. (2007), "Personal technologies and the teaching of professional dispositions in information technology", Innovation in Teaching and Learning in Information and Computer Sciences, Vol.6, No.1: 1-8

Johnson, M. \& Liber, O. (2008), "The personal learning environment and the human conditions: From theory to teaching practice", Interactive Learning Environments, Vol.16, No.1: 3-15.

Kenning, M. M. (2010), "Differences that make the difference: A study of functionalities in synchronous CMC", ReCALL, Vol.22: 3-19.

Kolah, D.\& Fosmire, M. (2010), "Information Portals: A New Tool for Teaching Information Literacy Skills", Issues in Science and Technology Librarianship :1-35

Lai,C. \& Li,G. (2011), "Technology and Task-Based Language Teaching: A Critical Review”, CALICO Journal, Vol.28, No.2:498-521.

Littlewood,W. (2003), The task-based approach: some questions and suggestions, Hong Kong: Hong Kong Institution of Education.

Martin, M. (2007), My personal learning environment, http://michelemartin. typepad.com/thebambooprojectblog/2007/04/my_personal_lea.html, retrieved in June 2014

Martindale, T., \& Dowdy, M. (2010), Personal learning environments: Emerging technologies in distance education, AB: Athabasca University Press. 
Mokhtar,S. \& Huoy,L.S. (2013), "Design of Personal Learning Environment Framework for Learner Autonomy", 4th International Conference on Computer Science and Information Technology, Dubai:10-14

Musa, A.H. (2007), “AN ASSESSMENT OF LISTENING COMPREHENSION OF PUPILS OF THE SECONDARY SCHOOLS”, Osar Ramzy Journal, Vol.3, No.5: 1-13

Natraj, S. (2005), Developing Communication Skills: A Handbook for Teachers \& Learners of English, Charutar Vidya Mandal: Vallabh Vidyanagar

Nunan,D. (2004), Task-Based Language Teaching, University of Hong Kong: Cambridge Press.

OER, S. (2012), Listening Skills, South Africa: South Africa Institute for Distance Education.

Ortega, L. (2009), "Task and technology in language learning: Elective affinities and (dis)encounters", Plenary delivered at the 3rd International TaskBased Language Teaching Conference, UK: Lancaster.

Panagiotidis,P. (2012), "PERSONAL LEARNING ENVIRONMENTS FOR LANGUAGE LEARNING”, SOCIAL TECHNOLOGIES, Vol. 2, No. 2: 420-440

Peña-López, I. (2010), Personal Learning Environments: blurring the edges of formal and informal learning, Working Paper

Perry, W.F. (2008), Creating a Personalized Learning Environment Using Pageflakes, http://www.slideshare.net/wfperry/creating-a-ple, retrieved in June 2014.

Plews, J. L.; Zhao, K. (2010), "Tinkering with tasks knows no bounds: ESL Teachers' Adaptations of Task-Based Language-Teaching", TESL Canada Journal, Vol.28, No.1: 41-59 
Pugazhenthi,M.A. (2013), "Identifying Fit between Competencies of Listening Skill Incorporated in the Samacheer Kalvi English Syllabus and CEFR Illustrative Scale", Language in India, Vol.13: 378-388

Ragupathi,K. (2011), "Using Personal Learning Environments (PLEs) to encourage peer learning and learner autonomy", Technology in Pedagogy, No.6: $1-6$

Reisas, S. (2012), "Diverse Knowledge Practices through Personal Learning Environments - A theoretical Framework", The PLE Conference, http://revistas.ua.pt/index.php/ple/article/view/1463, retrieved in June 2014

Rezaei,A. \& Hashim,F. (2013), "Impact of Awareness Raising about Listening Micro-skills on the Listening Comprehension Enhancement: An Exploration of the Listening Micro-skills in EFL Classes", Australian Journal of Teacher Education, Vol. 38, No. 8: 1-16

Richards, J. C. \& Rodgers, T. S. (2001), Approaches Methods in Language Teaching, Cambridge: Cambridge University Press

SA NCHEZ, A. (2004), "The Task-based Approach in Language Teaching", International Journal of English Studies, Vol. 4, No.1: 39-71

Sauro, S. (2004), "Cyberdiscursive tug-of-war: Learner repositioning in a multimodal CMC environment", Working Papers in Educational Linguistics, Vol.19, No.2: 55-72.

Scapin, R. (2009), Personal Learning Environment, Dawson College: Office of Instructional Development

Scott, E. (2012), Teaching ESL Listening, https://suite.io/edurne-scott/tts237, retrieved in August 2014.

Shaikh,Z.A. \& Khoja,S.A. (2012), "Role of Teacher in Personal Learning Environments", Digital Education Review, No.21, http://greav.ub.edu/der/. 
Skrabut,S.A. (2013), Personal Learning Environments: The Natural Way of Learning, University of Wyoming

Smith, B. (2010), Employing eye-tracking technology in researching the effectiveness of recasts in CMC, Heidelberg: Springer Verlag.

The National Capital Language Resource Center. (2004), Teaching Listening: Strategies for Developing Listening Skills, http://www.nclrc.org/essentials/listening/stratlisten.htm, retrieved in July 2014

Thomas,M. \& Reinders,H. (2010), “Task-Based Language Learning and Teaching with Technology", The Asian Journal, http://asian-efl-journal.com/taskbased-language-learning-and-teaching-with-technology/, Retrieved in May 2014

Thirachaimongkhonkun,C. \& Fathet,S. (2013), Task-Based Instruction (TBI), Thailand: Ongkharak.

Thouësny,S. \& Bradley,L. (2011), Second Language Teaching and Learning with Technology: Views of Emergent Researchers, Ireland

University of Cambridge. (2009), Experts in Language Assessment, UK: University of Cambridge.

Ur, P. (1984), Teaching Listening Comprehension, Cambridge University Press

Van Harmelen, M. (2008), "Design trajectories: Four experiments in PLE implementation", Interactive Learning Environments, Vol.16, No.1: $35-46$.

Waters, J. (2008), "Unleashing the power of Web 2.0", Campus Technology, Vol. 21, No.10: 44-49.

WikiEducator. (2010), Learning objects, personal learning environments, study guides, Retrieved in October 2013.

Willis,D. \& Willis,J. (2007), Doing Task-Based Teaching, OUP: Longman. 
Willis,J. (2002), Teaching English through a task-based approach, UK: OUP

Willis, J. (2013), From Grammar Point to Task-based Lesson, UK: Aston University.

Wilson, S. (2008), "Patterns of personal learning environments", Interactive Learning Environments, Vol.16, No.1: 17-34.

Xiang,C. (2013), "Research on the task-based Chinese teaching based on a multidimensional perspective", International Conference on Education Technology and Management Science, Atlantis Press: 1459-1462

الملخص

\section{بيئة تعلم شخصية قائمة على مدخل الأنشطة لتنمية مهارات الاستماع الاستيعابي لاى طلاب شعبة اللغة الانجليزية}

هدفت الدراسة الحالية إلى تتمية مهارات الاستماع الاستيعابي لدى طلاب اللغة الانجليزية بكلية التربية بالإسماعيلية (جامعة قناة السويس). وكانت تلك المهار ات هي: أ) مهارات الاستماع الاستيعابي الأساسية: (تخمين

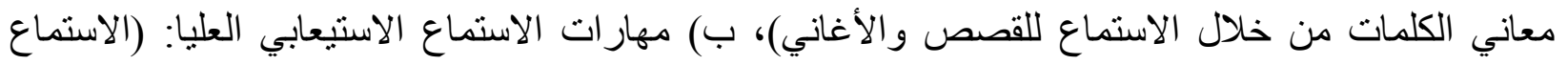

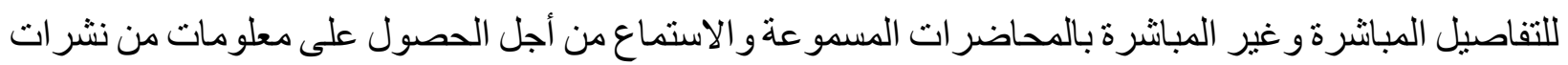
الطقس و الاخبار المسمو عة). كانت عينة الدر اسة مجمو عة من 30 طالب وطالبة بشعبة اللغة الانجليزية عام (الفرقة الأولى) بكلية التربية بالإسماعيلية (جامعة قناة السويس). وكان التصميم التجريبي للار اسة هو تصميم المجموعة الو احدة. وكانت أداة المعالجة التجريبية لتحقيق هذا الهدف هو موديول قائم على بيئة تعلم شخصية قائمة على مدخل الأنثطة. و أداة القياس للتحقق من الفروض وفاعلية البرنامج هو: اختبار الاستماع الاستيعابي. وقد نم التحقق من صدق وثبات تللك الأداة. وقد تم تطوير وتطبيق الموديول للتحقق من فاعليته وأسفرت نتائج الدراسة عن الأثر الإيجابي الدال للموديول في تنمية مهار ات الاستماع الاستيعابي المستهدفة لدى طلاب الفرقة الأولى بشعبة اللغة الإنجليزية عام باستخدام بيئة تعلم شخصية قائمة على مدخل الأنشطة.

الكلمات المفتاحية: مدخل الأنشطة، بيئة تعلم شخصية، مهار ات الاستماع، الاستماع الاستيعابي، وطلاب شعبة اللغة الانجليزية. 